\title{
Two new Zingiber species (Zingiberaceae) from Sorsogon, Philippines
}

\author{
R.V.A. Docot ${ }^{1}$, K.D. Gutierrez ${ }^{1}$, R.E.E. Mamalias ${ }^{1}$, N.B.R. Espino ${ }^{1}$, \\ A.A.B. Java ${ }^{1}$, C.D. Dineros ${ }^{1}$ \& E.M.L. Mijares ${ }^{2,3}$ \\ ${ }^{1}$ Department of Biological Sciences, Institute of Art and Sciences, Far Eastern University, \\ Nicanor Reyes Sr. Street, Sampaloc 1015, Manila, Philippines \\ dukerudolph@gmail.com \\ ${ }^{2}$ The Graduate School, University of Santo Tomas, España Boulevard, Sampaloc 1008, \\ Manila, Philippines \\ ${ }^{3}$ Education Department, Sorsogon State College, Magsaysay Street, Sorsogon City 4700, \\ Sorsogon, Philippines
}

\begin{abstract}
Two new species of gingers (Zingiberaceae), Zingiber aguingayae Docot and $Z$. subroseum Docot, are described and illustrated here based on recent collections from Mount Bulusan, Sorsogon, Philippines. Our rediscovery of the poorly known Zingiber bulusanense Elmer at the same locality not only allowed us to clarify its identity but also gave us stronger assurance that the two new species are indeed undescribed. Evidence from morphological and molecular data using the ITS region supported the placement of both new species and Zingiber bulusanense within Zingiber sect. Zingiber. The conservation status of the two new species were also assessed.
\end{abstract}

Keywords. Critically Endangered, ITS, Zingiber matutumense, Zingiber zerumbet

\section{Introduction}

Zingiber Mill. currently comprises c. 180 species distributed from India to Malesia and to the western Pacific islands (Theerakulpisut et al., 2012; Ardiyani et al., 2017; Zingiberaceae Resource Centre, 2019). The genus is recognised by the more or less sessile anther with an elongated crest which embraces the upper portion of the style (Smith, 1988). In the vegetative state, Zingiber can be readily distinguished by the swollen area between the base of the lamina and ligule called a pulvinus (LeongŠkorničková \& Newman, 2015). Zingiber is currently divided into four sections, Zingiber sect. Cryptanthium Horan., sect. Dymczewiczia (Horan.) Benth., sect. Pleuranthesis Benth., and sect. Zingiber(Baker, 1894; Schumann, 1904; Theerakulpisut et al., 2012). The sections are supported by morphological and molecular data (e.g. Theerakulpisut et al., 2012), and even with palynological data (e.g. Theilade et al., 1993), except for Zingiber sect. Dymczewiczia which Theilade et al. (1993) suggested should be included in Zingiber sect. Zingiber due to the variability of the position of the inflorescence, similarity in pollen morphology, and evidence based on ITS sequence data (Ye et al., 2015; Ardiyani et al., 2017). 
Zingiber is currently known in the Philippines from 13 species of which nine are endemic and four are widespread and cultivated (see table 1 for the list of species and history of the presence of each Zingiber of the Philippines). Blanco (1837) recorded and illustrated the widespread and economically important Zingiber officinale Roscoe as Amomum zingiber L. in his Flora de Filipinas. In 1886, Brown described a species, Zingiber brevifolium N.E.Br. (non Z. brevifolium K.Schum., 1899), based on cultivated material said to have originated from the Philippines. In 1905, Ridley reported the occurrence of Zingiber cassumunar Roxb. (= Z. montanum (J.Koenig) Link ex A.Dietr.) in the Philippines, based on the specimen A.D.E. Elmer 6255, but in 1919 Elmer identified this specimen as Adelmeria alba Elmer (=Adelmeria oblonga Merr.). Ridley (1909) published two species, Zingiber molle Ridl. and Z. pubisquamum Ridl., and reported the occurrence of the widespread and cultivated $Z$. zerumbet (L.) Roscoe ex Sm. in the Philippines. In 1915, Elmer published Zingiber sylvaticum Elmer, based on the specimen A.D.E. Elmer 9843, which is also one of the syntypes of Z. molle (Newman et al., 2004). Elmer (1915) argued that the spikes of A.D.E. Elmer 9843 are radical (borne terminal on a separate leafless shoot) and not terminal as indicated in the protologue of $Z$. molle. Also in 1915, Elmer described two species named after their respective type localities, namely Zingiber apoense Elmer and Z. negrosense Elmer. Later, Elmer (1919) described a species, Zingiber bulusanense Elmer, and a variety, $Z$. zerumbet var. magnum Elmer, both from Mount Bulusan, Sorsogon. The latter variety was synonymised by Merrill (1923) under Z. zerumbet since it was only differentiated by its much larger vegetative size. In the same paper, Merrill listed again the occurrence of Zingiber montanum (as Z. cassumunar) in the Philippines but noted that he has not seen any material from the Philippines despite mentioning a specimen, $H$. Cuming 1605, from Misamis, Mindanao (Pelser et al., 2011 onwards). Steiner (1959), having examined the material at PNH, listed Zingiber montanum (as Z. cassumunar) in her list of the Zingiberaceae of Manila, concluding that the species is native to the Philippines, although she mentioned that $Z$. montanum is cultivated around the country. Mood \& Theilade (2001) described two species named after their respective type localities, Zingiber banahaoense Mood \& Theilade and Z. matutumense Mood \& Theilade. Zingiber spectabile Griff., an introduced species from Peninsular Malaysia, is now establishing self-sustaining populations in some parts of the Philippines (e.g. Cuernos de Negros Mountains, Negros Oriental) and thus, becoming a naturalised species.

Specimens of at least seven Zingiber taxa were collected during recent botanical explorations of Mount Bulusan in 2018-2019. After careful examination and comparison of these specimens to known Zingiber taxa, especially those enumerated by Elmer (1919), the material was identified as Zingiber officinale, Z. spectabile, and $Z$. zerumbet, all of which are widespread and cultivated in the Philippines, and as Z. sylvaticum and Z. bulusanense, which are more restricted in distribution. The morphology of two more specimens, however, did not fit any known Zingiber taxa occurring elsewhere. Thus, we conclude that these specimens are of undescribed species which are described and illustrated here. Their conservation statuses are also assessed. The sectional placements of the two new species, along with Zingiber bulusanense, were also determined using morphological data and through the phylogenetic analysis of ITS sequence data. 
Table 1. The 15 Zingiber species currently known in the Philippines, their distribution status and their records of occurrence in the Philippines. An asterisk (*) indicates that the species has been recorded from Mount Bulusan, Sorsogon.

\begin{tabular}{|c|c|c|}
\hline Species & Distribution & $\begin{array}{l}\text { First recorded in } \\
\text { the Philippines }\end{array}$ \\
\hline Zingiber aguingayae Docot* & Endemic & here \\
\hline Zingiber apoense Elmer & Endemic & Elmer (1915) \\
\hline Zingiber banahaoense Mood \& Theilade & Endemic & $\begin{array}{l}\text { Mood \& Theilade } \\
(2001)\end{array}$ \\
\hline Zingiber brevifolium N.E.Br & Endemic & Brown (1886) \\
\hline Zingiber bulusanense Elmer * & Endemic & Elmer (1919) \\
\hline Zingiber matutumense Mood \& Theilade & Endemic & $\begin{array}{l}\text { Mood \& Theilade } \\
(2001)\end{array}$ \\
\hline Zingiber molle Ridl. & Endemic & Ridley (1909) \\
\hline $\begin{array}{l}\text { Zingiber montanum (J.Koenig) Link ex } \\
\text { A.Dietr. }\end{array}$ & $\begin{array}{l}\text { Widespread and } \\
\text { cultivated }\end{array}$ & Merrill (1923) \\
\hline Zingiber negrosense Elmer & Endemic & Elmer (1915) \\
\hline Zingiber officinale Roscoe* & $\begin{array}{l}\text { Widespread and } \\
\text { cultivated }\end{array}$ & Blanco (1837) \\
\hline Zingiber pubisquamum Ridl. & Endemic & Ridley (1909) \\
\hline Zingiber spectabile Griff.* & $\begin{array}{l}\text { Widespread and } \\
\text { cultivated }\end{array}$ & here \\
\hline Zingiber subroseum Docot* & Endemic & here \\
\hline Zingiber sylvaticum Elmer* & Endemic & Elmer (1915) \\
\hline Zingiber zerumbet (L.) Sm.* & $\begin{array}{l}\text { Widespread and } \\
\text { cultivated }\end{array}$ & Ridley (1909) \\
\hline
\end{tabular}

\section{Materials and methods}

Herbarium collections, including types and high resolution images of specimens, from BM, BO, E, F, FI, FEUH, G, GH, K, L, MO, NY, P, PNH, S, SING, U, US, USTH, and $\mathrm{Z}$, along with published morphological descriptions of the most similar species, and species occurring elsewhere, were examined and compared to our recently collected specimens. The herbarium acronyms follow Thiers (continuously updated). The extent of occurrence (EOO) and area of occupancy (AOO) were calculated using the Geospatial Conservation Assessment Tool (GeoCAT) (Bachman et al., 2011: www. geocat.kew.org). These data were then compiled to assess their conservation statuses 
using the International Union for Conservation of Nature (IUCN) criteria (IUCN, 2016).

Total genomic DNA was extracted from each species using DNeasy Plant Mini Kit (Qiagen ${ }^{\circledR}$, Germany) following the manufacturer's protocol. Amplification of the ITS region followed Docot et al. (2019). The leaf material sequenced was from recently collected specimens (Zingiber aguingayae: R.V.A. Docot et al. 0216, PNH, accession no. 256992; Z. bulusanense: R.V.A. Docot et al. 0213, FEUH, barcode 002950; Z. subroseum: R.V.A. Docot et al. 0204, PNH, accession no. 256991). PCR products were sent to Macrogen ${ }^{\odot}$ (Seoul, Korea) for purification and sequencing services. The new sequences were assembled and edited in Codon Code Aligner v. 4.1.1 (Codon Code, 2013) and were aligned using Mesquite v. 3.04 (Maddison \& Maddison, 2016) to the sequence data used by Ardiyani et al. (2017) (see table 2 for the complete accession details of the sequences used in this study). Maximum likelihood (ML) analysis of the ITS region was carried out using RaxML-HPC2 v. 8.2.10 (Stamakis, 2014) on CIPRES portal (Miller et al., 2010). Bootstrap support (BS) values were obtained by running 1000 replicates and were categorised according to Kress et al. (2002) standard cut-off values.

\section{Results and discussion}

We first compared the new material to the poorly known Zingiber bulusanense (Fig. 1), also from Mount Bulusan. The specimen R.V.A. Docot et al. 0213 (FEUH), also collected on Mount Bulusan, perfectly matched the protologue and the syntypes of Zingiber bulusanense in the dirty-brown hairs on the sheaths, ovoidly-ellipsoid spike, and the reddish exposed portion of the bract. Elmer (1919) described the basal part of the labellum of Zingiber bulusanense as densely veiny and spotted, and the lamina part as hyaline and spotted. Examination of R.V.A. Docot et al. 0213 flowers preserved in alcohol led us to conclude that Elmer was referring to the microscopic spots and veins of the labellum. In fact, even the margin of the bracts, bracteoles and corolla lobes, as well as the stamen, possess these spots which are visible only under the microscope.

Elmer (1919) emphasised that Zingiber bulusanense could be distinguished from all known Philippine Zingiber species at that time by the brown hairs on the sheaths (Fig. 1B). The two new species described here, however, have white hairs and are not as densely pubescent as Zingiber bulusanense. Zingiber bulusanense and one of the unknown species have ovoidly-ellipsoid spikes (Fig. 1C) but the colour of the spike of the latter is cream-pink and not red as in Zingiber bulusanense. Both Zingiber bulusanense and the other unknown species have red spikes but the shape of the spike of the latter is narrowly ovoid (oblong) and not ovoidly-ellipsoid as in Z. bulusanense. This unknown species can also easily be distinguished by its yellow flowers rather than the white flowers of Zingiber bulusanense.

The topology of the Maximum Likelihood tree produced in this study is congruent with Theerakulpisut et al. (2012) and with Ardiyani et al. (2017). Zingiber bulusanense and the two unknown species formed a moderately supported clade (BS 
Table 2. Voucher information and GenBank accession numbers of the sequences used in this study. GenBank accession numbers in bold text are newly generated sequences.

\begin{tabular}{|c|c|c|}
\hline Species & Distribution/Section & $\begin{array}{l}\text { GeneBank } \\
\text { Acc. No. } \\
\text { (ITS) }\end{array}$ \\
\hline \multicolumn{3}{|l|}{ Ingroups } \\
\hline Z. aguingayae Docot & Philippines/Zingiber & MK811015 \\
\hline Z. barbatum Wall. & Thailand/Zingiber & DQ064578 \\
\hline Z. bradleyanum Craib & Thailand/Cryptanthium & DQ064579 \\
\hline Z. bulusanense Elmer & Philippines/Zingiber & MK811016 \\
\hline Z. capitatum Roxb. (1) & India, Himalaya/Zingiber & KM983536 \\
\hline Z. capitatum (2) & India, Himalaya/Zingiber & KM983532 \\
\hline Z. citriodorum Theilade \& Mood & Thailand/Zingiber & DQ064591 \\
\hline Z. coloratum N.E.Br. & Borneo/Zingiber & AF414498 \\
\hline Z. corallinum Hance & Thailand, China/Zingiber & DQ064587 \\
\hline $\begin{array}{l}\text { Z. ellipticum (S.Q.Tong \& Y.M.Xia) Q.G.Wu } \\
\& \text { T.L.Wu }\end{array}$ & Yunnan-China/Pleuranthesis & AF478799 \\
\hline Z. fragile S.Q.Tong & Thailand/Cryptanthium & DQ064581 \\
\hline Z. gramineum Noronha ex Blume (1) & Indochina, Java, Sumatra/Zingiber & AF478800 \\
\hline Z. gramineum (2) & Indochina, Java, Sumatra/Zingiber & DQ064577 \\
\hline Z. isanense Triboun \& K.Larsen & Thailand/Zingiber & DQ064586 \\
\hline Z. junceum Gagnep. & Thailand/Zingiber & AY424774 \\
\hline Z. longipedunculatum Ridl. & Borneo/Zingiber & AB097254 \\
\hline Z. montanum (J.Koenig) Link ex A.Dietr. (1) & Cultivated/Zingiber & DQ064585 \\
\hline Z. montanum (2) & Cultivated/Zingiber & KJ872221 \\
\hline Z. neesanum (J.Graham) Ramamoorthy & India, Indochina/Zingiber & KJ872228 \\
\hline Z. newmanii Theilade \& Mood & Thailand/Zingiber & DQ064589 \\
\hline Z. odoriferum Blume (1) & Cultivated/Zingiber & KF304561 \\
\hline Z. odoriferum (2) & Cultivated/Zingiber & DQ064575 \\
\hline Z. officinale Roscoe & Cultivated/Zingiber & KF304562 \\
\hline Z. orbiculatum S.Q.Tong & Thailand/Cryptanthium & DQ064573 \\
\hline Z. ottensii Valeton (1) & Cultivated/Zingiber & AJ388298 \\
\hline Z. ottensii (2) & Cultivated/Zingiber & DQ064582 \\
\hline Z. parishii Hook.f. (1) & Thailand/Zingiber & DQ064576 \\
\hline Z. parishii (2) & Thailand/Zingiber & KF304567 \\
\hline Z. pellitum Gagnep. & Thailand/Dymczewiczia & DQ064574 \\
\hline Z. purpureum Roscoe (syn. of Z. montanum) & Cultivated/Zingiber & HM236153 \\
\hline Z. rubens Roxb. & Thailand/Cryptanthium & DQ064580 \\
\hline Z. spectabile Griff. & Sumatra, Malay Peninsula/Zingiber & AF414499 \\
\hline Z. subroseum Docot & Philippines/Zingiber & MK811017 \\
\hline Z. sulphureum Burkill ex Theilade & Sumatra, Malay Peninsula/Zingiber & AF478801 \\
\hline Z. ultralimitale Ardiyani \& A.D.Poulsen & Sulawesi/Zingiber & KU891639 \\
\hline Z. wrayi Prain ex Ridl. & $\begin{array}{l}\text { Sumatra, Malay Peninsula, } \\
\text { Thailand/Zingiber }\end{array}$ & AF478802 \\
\hline Z. zerumbet (L.) Roscoe ex Sm. (1) & Cultivated/Zingiber & KC582863 \\
\hline Z. zerumbet (2) & Cultivated/Zingiber & DQ064584 \\
\hline \multicolumn{3}{|l|}{ Outgroups } \\
\hline Kaempferia elegans (Wall.) Baker & China, Indochina, Malesia & AY424764 \\
\hline K. parviflora Wall. ex Baker & India, Indochina & DQ064592 \\
\hline
\end{tabular}



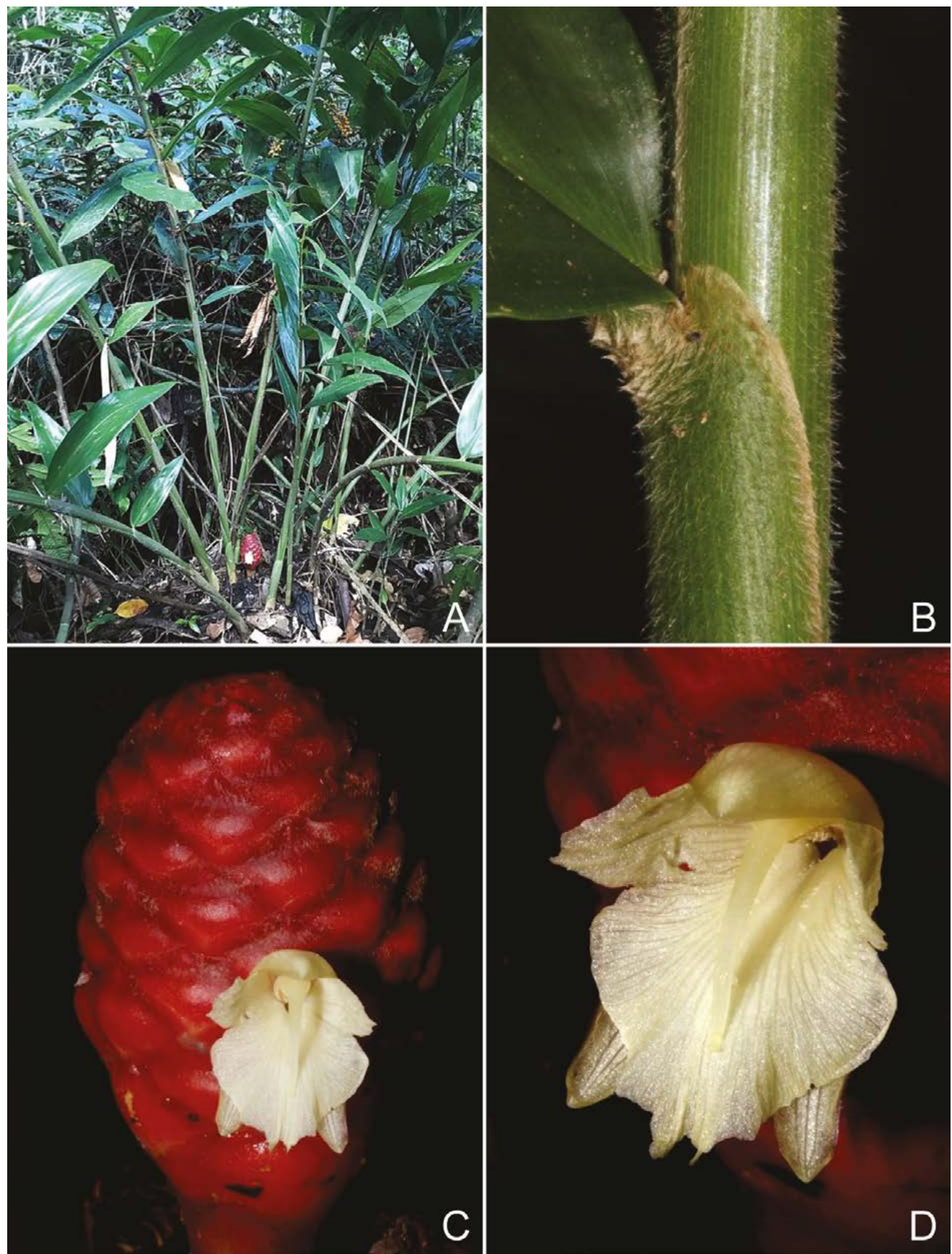

Fig. 1. Zingiber bulusanense Elmer. A. Habit. B. Ligule (notice the sheaths with brown hairs). C. Inflorescence. D. Flower at anthesis. Based on R.V.A. Docot et al. 0213 (FEUH) from Mount Bulusan, Sorsogon. (Photos: R.V.A. Docot). 
$=71 \%$ ) within Zingiber sect. Zingiber (Fig. 2). Moreover, the morphology of the three species also fits the circumscription of Zingiber sect. Zingiber (e.g. inflorescences borne on radical and erect peduncles; tightly imbricate floral bracts). With this morphological and molecular evidence, we place Zingiber bulusanense and the two unknown species within Zingiber sect. Zingiber and describe the two unknown species as new.

\section{Taxonomy}

\section{Zingiber aguingayae Docot, sp. nov.}

Similar to Zingiber matutumense Mood \& Theilade but differs in the much longer (2-3 vs 5-6 mm long) and pubescent ligule (vs glabrous); yellow corolla (vs light pink); obovate and yellow labellum (vs light pink and orbicular); and slightly pubescent ovary (vs glabrous) - TYPE: Philippines, Luzon, Sorsogon, Bulusan, Barangay San Roque, Mount Bulusan, 12 ${ }^{\circ} 45^{\prime} 36.1^{\prime \prime} \mathrm{N}, 14^{\circ} 05^{\prime} 32.1^{\prime \prime E}, 433$ m, 28 October 2018, R. V.A. Docot et al. 0216 (holotype PNH [accession no. 256992]; isotypes FEUH incl. spirit, L, USTH) (Fig. 3 \& 4).

Terrestrial herb. Rhizome 1.6-2.2 cm wide, brown externally, yellowish internally. Leafy shoots in dense clumps of 4-10 pseudostems, 1-2 $\mathrm{m}$ tall, arching to various degrees, base c. $1 \mathrm{~cm}$ wide; sheaths mid-green, pubescent; ligule bilobed, ovate, the lobes equal in size, 9-11 $\times 5-6 \mathrm{~mm}$, mid-green, pubescent, semi-membranous, apex rounded; petiole 5-7 mm long, densely pubescent; lamina narrowly ovate, 28-33 $\times 6-7 \mathrm{~cm}$, plicate, mid-green and glabrous on both sides, light green beneath, base attenuate, apex sharply attenuate, margin entire. Inflorescences $2-4$ per clump, arising close to the base of the leafy shoot, erect, 28-35 cm long, 1-2 flowers opening at a time; peduncle 20-25 cm long, almost half its length partially subterranean; peduncular bracts narrowly ovate, $4-5 \times 1.7-2 \mathrm{~cm}$, reddish brown, pubescent, apex rounded; spike narrowly ovoid (oblong), 9-13 $\times 4-5 \mathrm{~cm}$, tapering to an acute apex; floral bracts obovate, 3.6-4 × 3.8-4.3 cm, becoming smaller toward the base, the exposed part red, the remaining white, sparsely villose, apex rounded, the tip mucronate, margin entire with spots; bracteoles split to the base, wrapped around the flower (appearing tubular), narrowly obovate, 3.8-4 × 1.5-2 cm, white, sparsely villose, apex acute, reddish, margin with spots; flower sessile, 5.5-6.3 cm long; calyx 18-22 $\times 9-12 \mathrm{~mm}$, translucent white, with spots in the upper half, sparsely villose, with three inconspicuous teeth at the apex, with a 9-11 mm unilateral incision; corolla tube 3-3.5 cm long, whitish yellow, glabrous throughout except the slightly pubescent base; corolla lobes yellow, with spots along the margin, glabrous, apex obtuse and cucullate; dorsal corolla lobe narrowly ovate, $22-27 \times 9-12 \mathrm{~mm}$; lateral corolla lobes narrowly linear, 23-25 $\times$ 4-6 mm; labellum petaloid, 1.8-2.4 × 1.5-2 cm, yellow, central part with spots (under the microscope), apex bifid, incision 3-4 mm; lateral staminodes petaloid, obovate, $13-15 \times 5-8 \mathrm{~mm}$, apex obtuse to acute. Stamen $2.5-3 \mathrm{~cm}$ long, filament fully reduced; anther 13-16 $\times 4-6 \mathrm{~mm}$, yellow, with spots beneath, pubescent; crest $1.2-1.5 \mathrm{~cm}$ long (when stretched), enveloping the upper portion of the style, incurved, yellow, with 


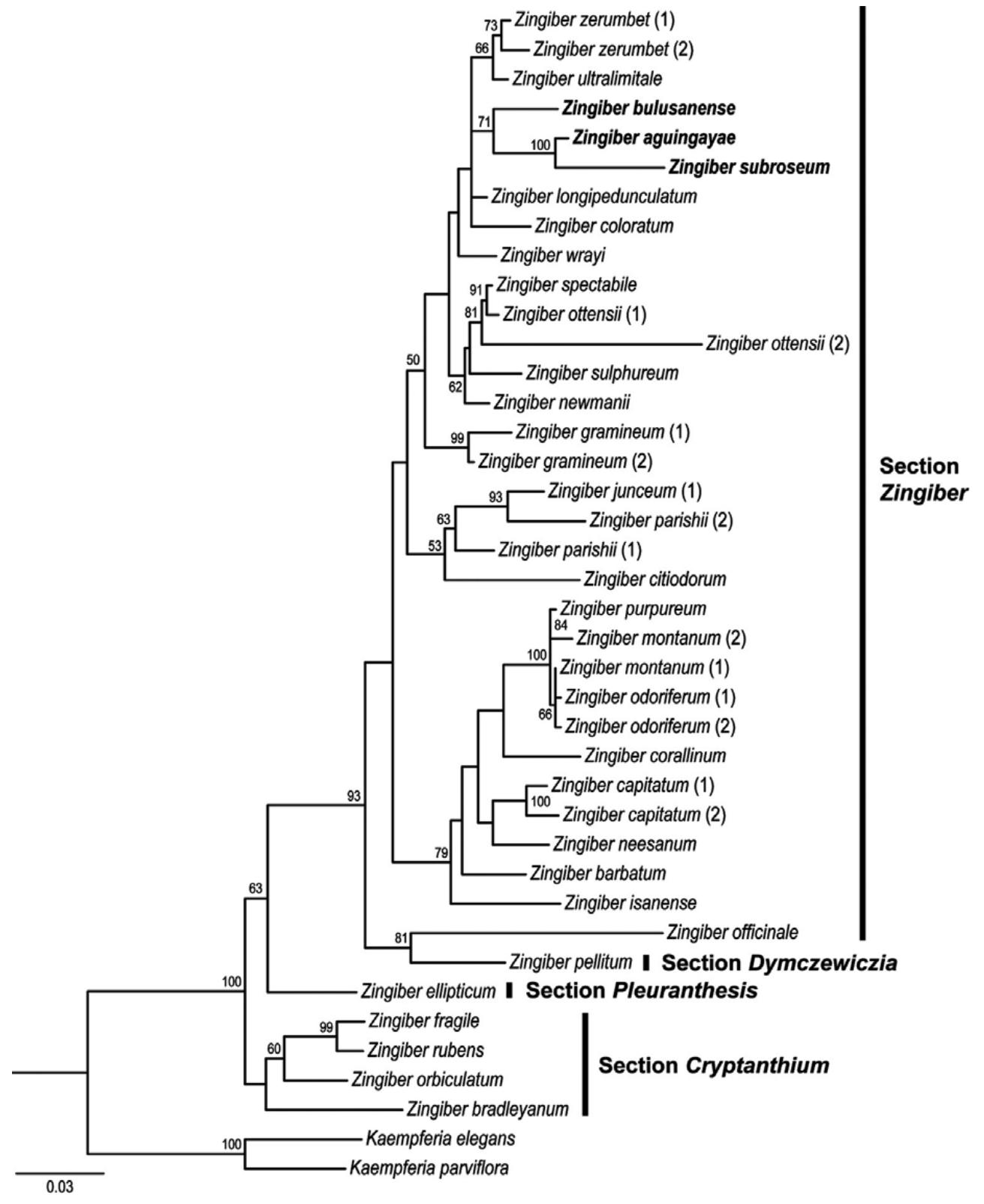

Fig. 2. Maximum Likelihood phylogenetic tree of Zingiber using ITS sequence data. The four sections of Zingiber are indicated. Bootstrap values obtained are presented above the branches. Only bootstrap values higher than 50\% are shown. Taxa included in this study for the first time are marked in bold, while additional material downloaded from GenBank is in normal font. 


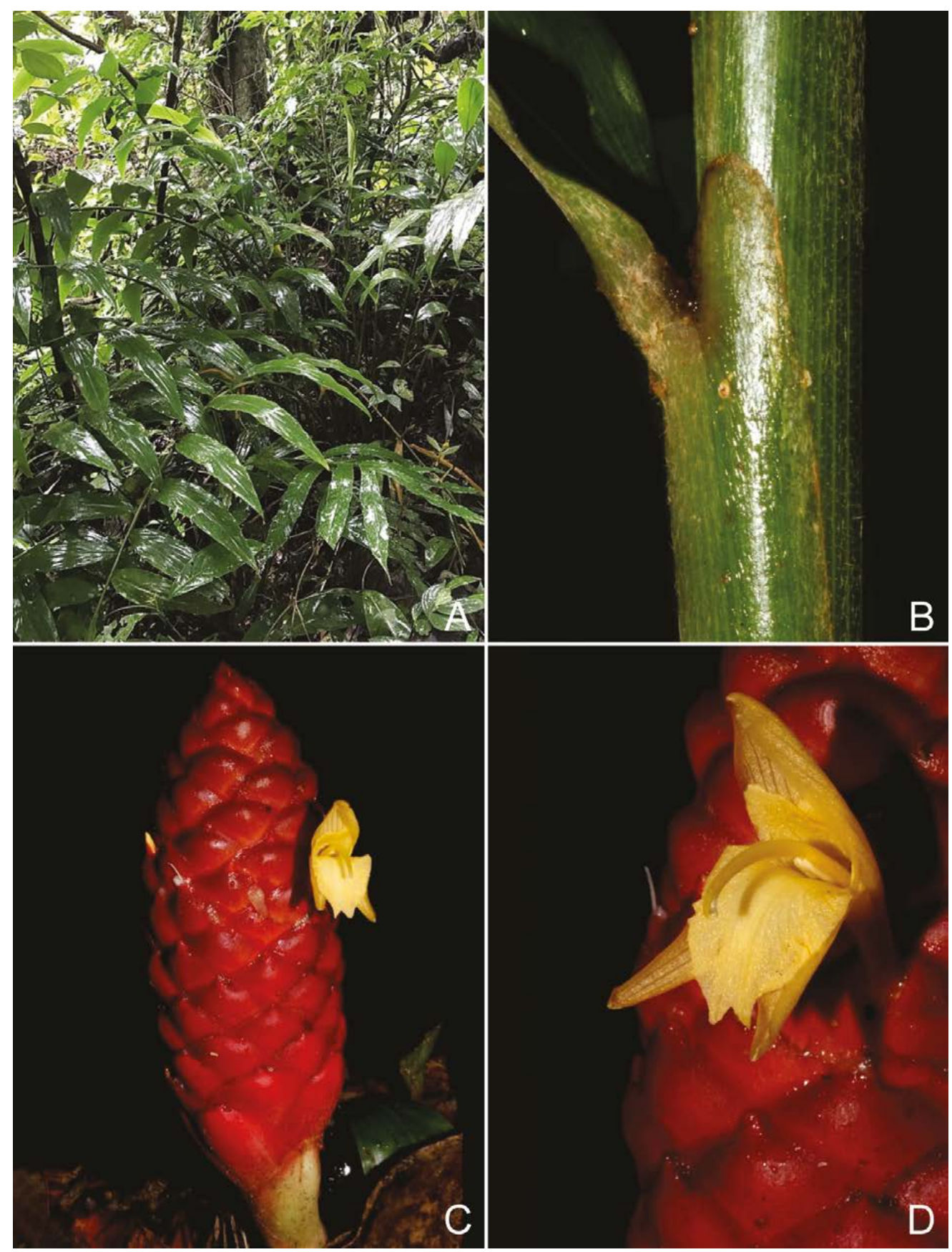

Fig. 3. Zingiber aguingayae Docot. A. Habit. B. Ligule. C. Inflorescence. D. Flower at anthesis. Based on R.V.A. Docot 0216 et al. (type) from Mount Bulusan, Sorsogon. (Photos: R.V.A. Docot). 


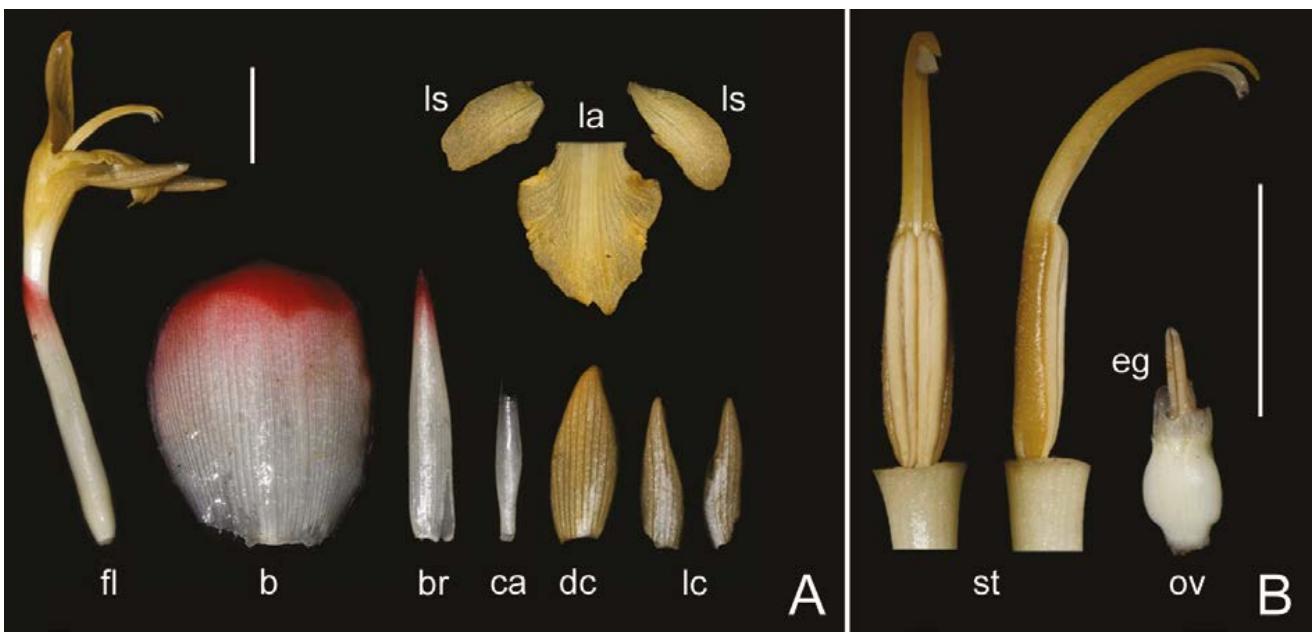

Fig. 4. Zingiber aguingayae Docot. A. Floral dissection (b. bract, br. bracteoles, ca. calyx, dc. dorsal corolla lobe, fl. flower, la. labellum, lc. lateral corolla lobes, ls. lateral staminodes). B. Details of anther and ovary with epigynous glands (eg. epigynous glands, ov. ovary, st. stamen). Based on R.V.A. Docot 0216 et al. (type) from Mount Bulusan, Sorsogon. Scale bars $=1 \mathrm{~cm}$. (Photos: R.V.A. Docot).

spots; theca opening throughout its length, light yellow, glabrous. Style 5-6.5 cm long, whitish yellow, with spots, glabrous; stigma c. $1 \mathrm{~mm}$ wide, whitish yellow, with spots, ostiole with straight ciliae; epigynous glands subulate, 4-5 $\mathrm{mm}$ long, yellow; ovary subglobose, 7-9 × 4-6 mm, trilocular, axile placentation, white, slightly pubescent. Fruit not seen.

Distribution and habitat. Zingiber aguingayae is only known from the type locality where it inhabits semi-shaded areas of secondary forest at 300-600 m asl.

Phenology. Only a few flowering individuals were observed in late October. Some inflorescences were already dried and rotten leading to the conclusion that mass flowering may have occurred early to mid-September.

Etymology. The specific epithet is named after Aguingay, the legendary mistress of the warrior Bulusan, characters from the popular Bulusan-Sorsoganon-Bicol folklore titled 'Si Bulusan nan si Aguingay', set in the locality where the species was discovered.

Provisional IUCN conservation assessment. Based on the IUCN red list categories and criteria (IUCN, 2016), Zingiber aguingayae is categorised as Critically Endangered CR B2ab(iii). The area of occupancy is estimated to be less than $10 \mathrm{~km}^{2}$ (total area of occupancy is c. $4 \mathrm{~km}^{2}$ ) and it is only known from the one location on Mount Bulusan. Only three subpopulations were observed 200-300 m apart. Fortunately, Zingiber aguingayae is within the Bulusan Volcano Natural Park, a 3673-hectare protected 
area in the Philippines. Surveys were also conducted to try and find populations on neighbouring mountains (e.g. Pocdol Mountains between the provinces of Albay and Sorsogon) although none was found. A possible threat is the continuous volcanic activity of Mount Bulusan which could wipe out the entire population of the species since it is the $4^{\text {th }}$ most active volcano in the Philippines (de la Cruz, 2015). Another threat could be due to anthropogenic activities (e.g. widening of trails) since Mount Bulusan is also one of the most popular mountains in the Philippines for hiking.

Notes. The most similar species based on overall morphology is Zingiber matutumense of South Cotabato, Mindanao. Although the leafy shoots of both Zingiber aguingayae and $Z$. matutumense can reach 1-2 $\mathrm{m}$ tall, Z. aguingayae can be readily distinguished in its vegetative state by the much longer (5-6 vs $2-3 \mathrm{~mm}$ long) and pubescent ligule (vs glabrous in Z. matutumense). In floral morphology, both Zingiber aguingayae and Z. matutumense have narrowly ovoid red spikes. In Zingiber aguingayae, the spike is narrowly ovate throughout its reproductive phase. In Zingiber matutumense, however, the spike is initially ovoid and then turns narrowly ovoid upon maturity (Mood \& Theilade, 2001). The most observable difference between the two species is the colour of the corolla and labellum which is yellow in Zingiber aguingayae and light pink in Z. matutumense. The shape of the labellum of Zingiber aguingayae is obovate (Fig. 4) and in Z. matutumense it is orbicular.

Interestingly, a series of photographs uploaded on the website of Co's Digital Flora of the Philippines (http://www.phytoimages.siu.edu/imgs/pelserpb/r/ Zingiberaceae_Zingiber_matutumense_55560.html) from the province of Oriental Mindoro (initially identified as Zingibermatutumense) may be actually of Z. aguingayae due to its narrowly ovoid spike and yellow flowers. The apex of the labellum based from the photographs, however, is entire (vs bifid in Z. aguingayae). If it proves to be identical or within the morphological variation of Zingiber aguingayae it will extend its distribution to Oriental Mindoro.

\section{Zingiber subroseum Docot, sp. nov.}

Similar to Zingiber zerumbet (L.) Roscoe ex Sm. but distinct in the petiolate lamina (vs sessile); significantly shorter peduncle (9-11 vs 10-30 cm long) and wider spike (8-10 vs 4-6 cm wide); cream-pink floral bract (vs mid green); and cream-pink fruiting spike (vs bright red). - TYPE: Philippines, Luzon, Sorsogon, Casiguran, Barangay Inalgadian, Mount Bulusan, 1246'49.3"N, 12403'42.9"E, 993 m, 25 October 2018, R.V.A. Docot et al. 0204 (holotype PNH [accession no. 256991]; isotypes FEUH incl. spirit, L, USTH) (Fig. 5-7).

Terrestrial herb. Rhizome 1.5-2 cm wide, fleshy, brown externally, yellowish internally. Leafy shoots in a loose clump of 2-5 pseudostems, 1-3 $\mathrm{m}$ tall, arching to various degrees, base c. $9 \mathrm{~mm}$ wide; sheaths mid-green, pubescent, the margin brownish; ligule bilobed, ovate, pubescent, semi-membranous, apex rounded, the larger lobe 6-10 $\times 5-7 \mathrm{~mm}$, reddish brown, the smaller lobe 4-7 $\times 3-5 \mathrm{~mm}$, light 


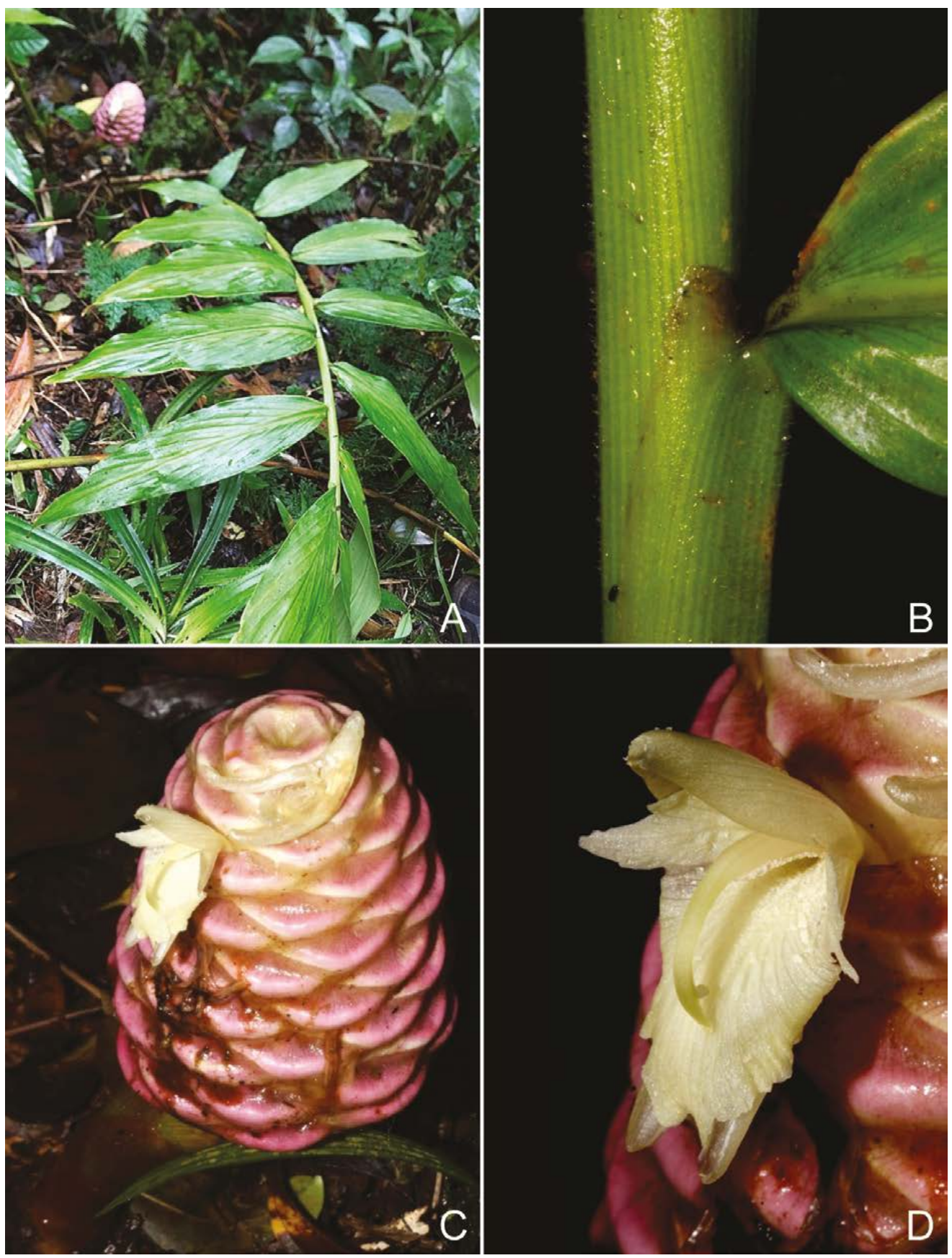

Fig. 5. Zingiber subroseum Docot. A. Habit. B. Ligule. C. Inflorescence. D. Flower at anthesis. Based on R.V.A. Docot 0204 et al. (type; A-D) from Mount Bulusan, Sorsogon. (Photos: R.V.A. Docot). 

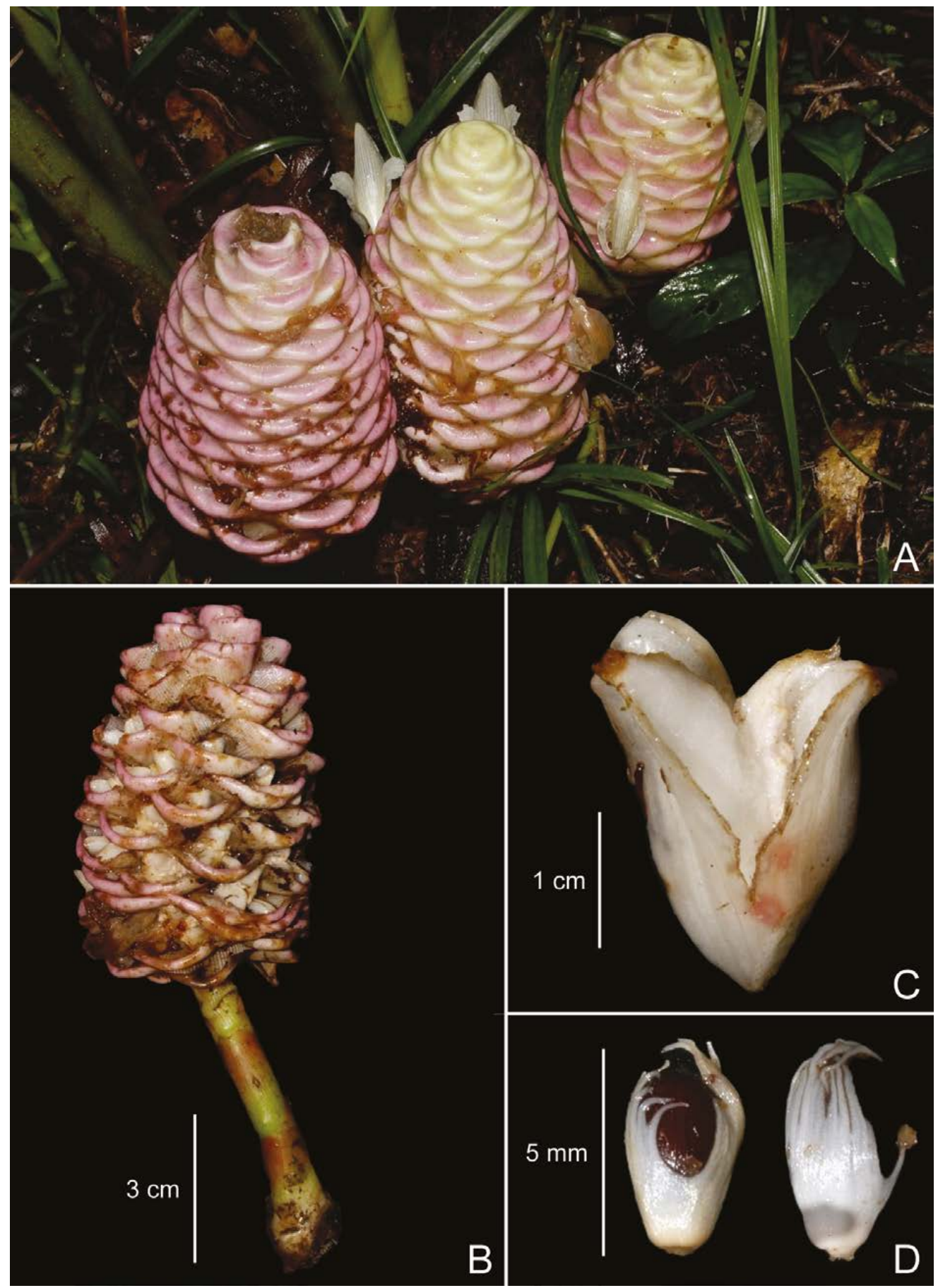

Fig. 6. Zingiber subroseum Docot. A. Inflorescences. B. Infructescence. C. Fruit. D. Seeds. Based on R.V.A. Docot 0204 et al. (type; A) and R.V.A. Docot 0230 et al. (B-D) from Mount Bulusan, Sorsogon. (Photos: R.V.A. Docot). 


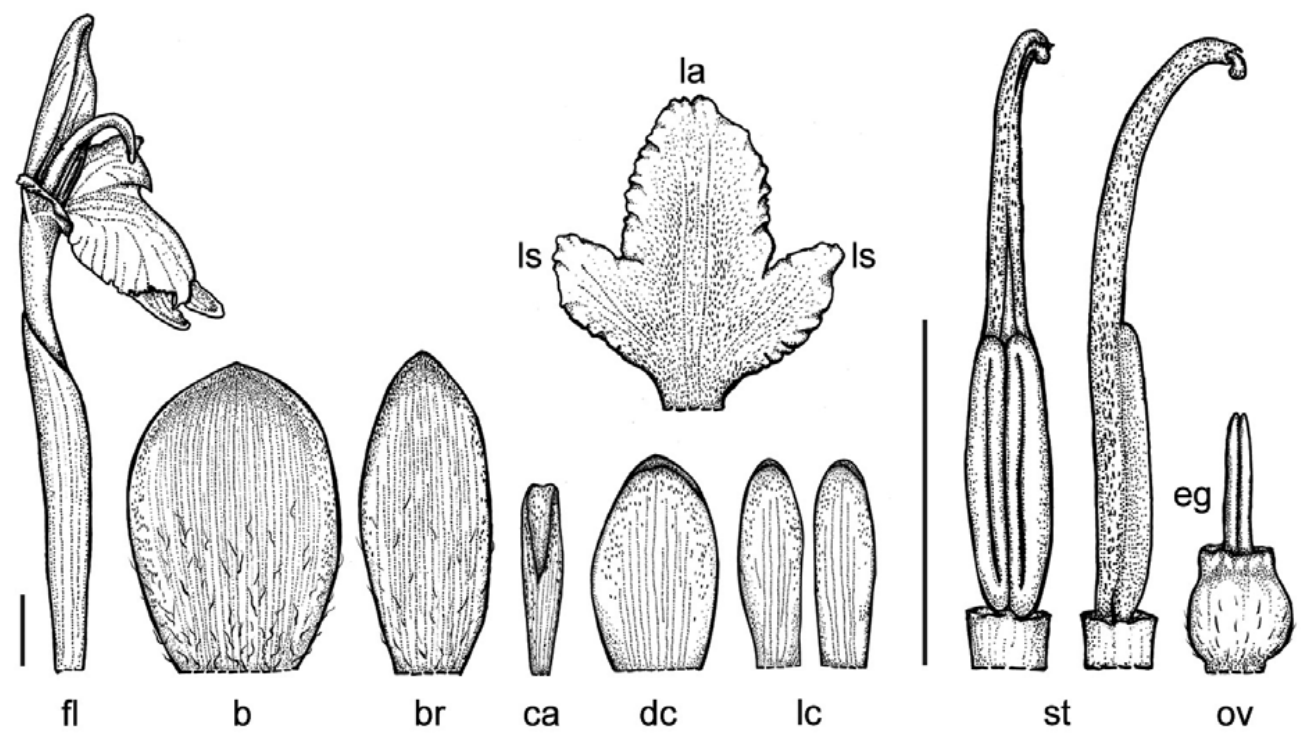

Fig. 7. Zingiber subroseum Docot floral dissection. (b. bract, br. bracteoles, ca. calyx, dc. dorsal corolla lobe, eg. epigynous glands, fl. flower, la. labellum, lc. lateral corolla lobes, Is. lateral staminodes, ov. ovary, st. stamen). Scale bars $=1 \mathrm{~cm}$. Drawn by K.D. Gutierrez from spirit material of R.V.A. Docot 0204 et al. (type) from Mount Bulusan, Sorsogon. B. Details of anther and ovary with epigynous glands (eg.)

green; petiole 4-7 $\mathrm{mm}$ long, channelled above, pubescent; lamina narrowly ovate, 25-30 $\times$ 5-7 cm, plicate, mid-green and glabrous above, light green and slightly pubescent beneath, base rounded when fresh, becoming attenuate when dried, apex sharply acuminate, margin entire, pubescent. Inflorescences 1-3 per clump, arising close to the base of the leafy shoot, erect, $24-31 \mathrm{~cm}$ long, 1-2 flowers opening at a time; peduncle 9-11 cm long; peduncular bracts 5-6 $\times 1-2 \mathrm{~cm}$, reddish green, pubescent outside, glabrous inside; spike ovoidly-ellipsoid, 15-20 × 8-10 cm; floral bracts obovate, becoming smaller towards the base, the exposed part cream-pink, turning dark pink upon maturity, the remaining white, sparsely villose, apex obtuse to acute, margin entire and pubescent, with spots; bracteoles open to the base, wrapped around the flower (appearing tubular), 3.5-4 × 1.5-2 cm, translucent white, sparsely villose, apex 3-dentate, with spots, pubescent; flower 6-7 cm long; calyx tubular half of its length from the base, 2-2.5 $\times 1-1.5 \mathrm{~cm}$ when flattened, white, slightly villose, with three inconspicuous teeth at the apex which are tufted with a few hairs, with a 8-10 mm long unilateral incision; corolla tube c. $45 \mathrm{~mm}$ long, white, with very few hairs in the upper portion, glabrous inside; corolla lobes white with translucent veins, with spots along the margin, glabrous, apex obtuse and cucullate; dorsal corolla lobe ovate, $2.5-3 \times 1.5-1.8 \mathrm{~cm}$; lateral corolla lobes narrowly ovate, $25-30 \times 4-7 \mathrm{~mm}$; labellum ovate, petaloid, 2.6-3.2 $\times 1.5-2 \mathrm{~cm}$, recurved at anthesis, whitish yellow, glabrous throughout, apex bifid, incision c. $4 \mathrm{~mm}$ long; lateral staminodes petaloid, 
5-8 $\times 10-17 \mathrm{~mm}$, white. Stamen $1.7-2 \mathrm{~cm}$ long, filament fully reduced; anther 7-9 $\times 2-2.4 \mathrm{~mm}$; crest $1-1.4 \mathrm{~cm}$ long (when stretched), enveloping the upper portion of the style, incurved, yellowish white; theca opening throughout its length, whitish yellow, glabrous throughout. Style 5-7 cm long, white, glabrous; stigma c. $1.5 \mathrm{~mm}$ wide, white, with spots, ostiole with straight ciliae; epigynous glands subulate, 2-3 $\mathrm{mm}$ long, yellow; ovary subglobose, 5-7 × 3-4 mm, trilocular, axile placentation, white, slightly pubescent. Fruit obovoid, dehiscing into three parts, 25-32 × 9-13 $\mathrm{mm}$, white, glabrous; seed obovoid, partially covered with sac-like white aril, 5-7 $\times$ 3-4 mm, dark brown.

Distribution and habitat. Zingiber subroseum is only known from the type locality where it inhabits densely shaded primary forest at 700-1000 $\mathrm{m}$ asl.

Phenology. Flowering individuals were observed in late October while fruiting individuals in early February.

Etymology. The specific epithet refers to its cream-pink floral bracts.

Provisional IUCN conservation assessment. Based on the IUCN red list categories and criteria (IUCN, 2016), Zingiber subroseum is categorised as Critically Endangered CR B2ab(iii). The area of occupancy is estimated to be less than $10 \mathrm{~km}^{2}$ (total area of occupancy is c. $4 \mathrm{~km}^{2}$ ) and it is only known from the one location on Mount Bulusan. The observed population within the natural park was only of ten individuals over c. $200 \mathrm{~m}$ since the species only inhabits shaded high elevation forest. Fortunately, the area where Zingiber subroseum was collected (Casiguran side) is still within the 3673-hectare protected area of the mountain. As with Zingiber aguingayae, the threats are the same and no populations were observed on neighbouring mountains.

Notes. Zingiber subroseum is the only Philippine species with a cream-pink spike (Fig. 5C \& 6A). The most closely related species based on overall morphology is the widespread and cultivated Zingiber zerumbet originally described from Sri Lanka. The leafy shoots of both Zingiber subroseum and Z. zerumbet can reach up to $3 \mathrm{~m}$ tall, although there are some reports that $Z$. zerumbet can reach up to $5 \mathrm{~m}$ tall. In the vegetative state, Zingiber subroseum can easily be distinguished from $Z$. zerumbet by the petiolate lamina (vs sessile in $Z$. zerumbet). The most noticeable differences between the two species are in the reproductive parts. For example, the peduncle of Zingiber subroseum is usually shorter than that of $Z$. zerumbet $(9-11$ vs $10-30 \mathrm{~cm}$ long), and the width of the spike of $Z$. subroseum is wider than that of $Z$. zerumbet (8-10 vs 4-6 cm wide). Zingiber subroseum can readily be distinguished from $Z$. zerumbet by the cream-pink flowering and fruiting spike of the former and the midgreen turning bright red upon fruiting of the latter. No common names or uses were reported by our local guides. 
Additional specimen examined. PHILIPPINES. Luzon, Sorsogon, Casiguran, Barangay Inalgadian, Mount Bulusan, 1246'49.4"N, 12403'43.0"E, 996 m, 3 Mar 2019, Docot 0264 (FEUH, USTH).

ACKNOWLEDGEMENTS. We thank the keepers of the herbaria at BM, E, FEUH, K, PNH and USTH for allowing us to view and examine their collections. The collection permits were issued by the Department of Environment and Natural Resources (DENR) Region $\mathrm{V}$ and PENRO Sorsogon with the help of former PASu M.D. Tengco, M.J.C. Ashred, and R.D. Papa. We thank G.C.V. Gamus, C.B.M. Domingo, V. Gallanosa of MENRO Bulusan, Barangay Inalgadian, Casiguran, Barangay Cogon, Irosin, and the Aggrupation of Advocates for Environmental Protection (AGAP) - Bulusan, Inc., headed by Philip Bartilet together with Ms. A. Bo, for their help during the fieldwork. A.D. Poulsen is thanked for useful information and insights, and the University Research Center (URC) of the Far Eastern University headed by S.L. Yap for the financial grant and laboratory facilities.

\section{References}

Ardiyani, M. Newman, M.F. \& Poulsen, A.D. (2017). A new species of Zingiber (Zingiberaceae) east of Wallace's Line. Gard. Bull. Singapore 69(2): 189-199.

Bachman, S., Moat, J., Hill, A.W., de Torre, J. \& Scott, B. (2011). Supporting Red List threat assessments with GeoCAT: geospatial conservation assessment tool. In: Smith, V. \& Penev, L. (eds) e-Infrastructures for data publishing in biodiversity Science. ZooKeys 150: $117-126$.

Baker, J.G. (1894). Scitamineae. In: Hooker, J.D. (ed.) The Flora of British India, vol. 6, pp. 198-264. London: L. Reeve \& Co.

Blanco, F.M. (1837). Flora de Filipinas, segun el sistema sexual de Linneo. Manila: Imprenta de Sto. Tomás por D. Candido Lopez.

Brown, N.B. (1886). New Garden Plants. Gard. Chron. n.s. 26: 390.

Codon Code (2013). CodonCode Aligner, ver. 4.1.1. Centerville, MA: CodonCode Corp.

de la Cruz, G. (2015). FAST FACTS: Mt. Bulusan, the PH's 4th most active volcano. https:// www.rappler.com/move-ph/issues/disasters/knowledge-base/92519-fast-facts-mountbulusan-active-volcano. Accessed 5 Jan. 2019.

Docot, R.V.A., Banag, C.I., Tandang, D.N., Funakoshi, H. \& Poulsen, A.D. (2019). Recircumscription and revision of the genus Vanoverberghia (Zingiberaceae). Blumea 64(2): $140-157$.

Elmer, A.D.E. (1915). Notes and descriptions of Zingiberaceae. Leafl. Philipp. Bot. 2: 2885-2919.

Elmer, A.D.E. (1919). Zingiberaceae of the Sorsogon peninsula. Leafl. Philipp. Bot. 8: 2963-2995.

IUCN Standards and Petitions Subcommittee (2016). Guidelines for Using the IUCN Red List categories \& criteria, ver. 12. https://www.iucnredlist.org/documents/ RedListGuidelines.pdf. Accessed 27 Nov. 2018.

Kress, W.J., Prince, L.M. \& Williams, K.J. (2002). The phylogeny and a new classification of the gingers (Zingiberaceae): evidence from molecular data. Am. J. Bot. 89: 1682-1696.

Leong-Škorničková, J. \& Newman, M.F. (2015). Gingers of Cambodia, Laos, and Vietnam. Singapore: Singapore Botanic Gardens, Natural Parks Board. 
Maddison, W.P. \& Maddison, D.R. (2016). Mesquite: a modular system for evolutionary analysis, ver. 3.10. Available from http://mesquiteproject.org. Accessed 29 Oct. 2018.

Merrill, E.D. (1923). An enumeration of Philippine flowering plants, vol. 1. Manila, Philippines: Bureau of Science.

Miller, M.A., Pfeiffer, W. \& Schwartz, T. (2010). Creating the CIPRES science gateway for inference of large phylogenetic trees. In: Proceedings of the gateway computing environments workshop (GCE), pp. 1-8. New Orleans, LA: IEEE.

Mood, J. \& Theilade, I. (2001). Two new species of Zingiber (Zingiberaceae) from the Philippines. Nordic J. Bot. 21: 128-134.

Newman, M.F., Lhuillier, A. \& Poulsen, A.D. (2004). Checklist of the Zingiberaceae of Malesia. Blumea, Suppl. 16. Leiden: Nationaal Herbarium Nederland, Universiteit Leiden Branch.

Pelser, P.B., Barcelona, J.F. \& Nickrent, D.L. (eds) (2011 onwards). Co's Digital Flora of the Philippines. http://www.philippineplants.org. Accessed 18 Nov. 2018.

Ridley, H.N. (1905). Scitimineae Philippinenses. Publ. Bur. Sci. Gov. Lab. 35(1): 83-87.

Ridley, H.N. (1909). The Scitamineae of the Philippine Islands. Philipp. J. Sci. 4: 155-199.

Schumann, K. (1899). Monographie der Zingiberaceae von Malaisien und Papuasien. Bot. Jahrb. Syst. 27: 259-350.

Schumann, K. (1904). Zingiberaceae. In: Engler, H.G.A. (ed.) Das Pflanzenreich, IV(46), fas. 20, pp. 1-458. Leipzig: W. Engelmann.

Smith, R.M. (1988). A review of Bornean Zingiberaceae: V (Zingiber). Notes Roy. Bot. Gard. Edinburgh 45: 409-423.

Stamakis, A. (2014). RAxML version 8: A tool for phylogenetic analysis and post-analysis of large phylogenies. Bioinformatics 30(9): 1312-1313.

Steiner, M.L. (1959). A new and illustrated flora of Manila, I Zingiberaceae. Philipp. J. Sci. 88(1): $1-40$.

Theerakulpisut, P., Triboun, P., Mahakham, W., Maensiri, D., Khampila, J. \& Chantaranothai, P. (2012). Phylogeny of the genus Zingiber (Zingiberaceae) based on nuclear ITS sequence data. Kew Bull. 67: 389-395.

Theilade, I., Mærsk-Møller, M.L., Theilade, J. \& Larsen, K. (1993). Pollen morphology and structure of Zingiber (Zingiberaceae). Grana 32: 338-342.

Thiers, B. (continuously updated). Index Herbariorum: A global directory of public herbaria and associated staff. New York Botanical Garden's Virtual Herbarium. http://sweetgum. nybg.org/science/ih/. Accessed 17 Nov. 2018.

Ye, Y.-S., Bai, L. \& Xia, N.-H. (2015). Zingiber hainanense (Zingiberaceae), a new species from Hainan, China. Phytotaxa 217(1): 73-79.

Zingiberaceae Resource Centre. (2019). Royal Botanic Garden Edinburgh. http://padme.rbge. org.uk/ZRC/welcome. Accessed 19 Jan. 2019. 
